\title{
The role of achievement goal orientations and interest on metacognitive strategy use of preservice science teachers
}

\author{
Volkan Atasoy \\ Middle East Technical University, Faculty of Education, Elementery Science Education Department, Ankara, \\ Türkiye,vatasoy5@gmail.com
}

\begin{abstract}
The purpose of this study was to determine contribution of achievement goal orientations and personal interest on prediction of metacognitive strategy use of preservice science teachers. This study was conducted with three hundred and twenty-two preservice science teachers who are freshmen, sophomore, junior and senior of elementary science education program. Data was collected by using three instruments which are "Metacognitive Self-Regulation Subscale ofMotivated Strategies for Learning Questionnaire", "Achievement Goals Questionnaire" and "The Academic Interest Questionnaire". Data was controlled with respect to reliability and validity. The collected data was analyzed by hierarchical regression. Results of this analysis showed that mastery approach goal orientation predicted significantly metacognitive strategy use of preservice science teacher in science course. On the other hand, mastery avoidance, performance approach, performance avoidance goal orientations and personal interest was not founded to predict significantly to metacognitive strategy use.

Keywords Achievement goal orientations, personal interest, metacognitive strategy.
\end{abstract}

ÖZ Bu çalışmanın amacı, fen bilgisi öğretmen adaylarının başarı hedefi yönelimleri ve kişisel ilgilerinin bilişüstü strateji kullanımını yordamadaki katkısını belirlemektir. Bu çalışma, ilköğretim fen bilgisi eğitimi programında okuyan birinci, ikinci, üçüncü ve dördüncü sınıfta olan toplam 322 fen bilgisi öğretmen adayı ile yürütülmüştür. Veriler, "Öğrenmede Güdüsel Stratejiler Ölçeğinin Bilişüstü Özdüzenleme Alt Ölçeği”, "Başarı Hedefleri Anketi” ve "Akademik İlgi Anketi" kullanarak toplanmıştır. Güvenirlik ve geçerlilik açısından, veriler kontrol edilmiştir. Daha sonra, bu veriler hiyerarşik regresyon ile analiz edilmiştir. Araştırma bulguları sonucunda, ustalık-yaklaşım hedef yöneliminin, bilişüstü strateji kullanımını önemli ölçüde istatiksel olarak yordadığı görülmüştür. Bunun yanında, ustalık-kaçınma hedef yöneliminin, başarım-yaklaşım hedef yönelimi, başarım-kaçınma hedef yönelimi ve kişisel ilgilerin bilişüstü strateji kullanımı önemli ölçüde tahmin etmediği bulunmuştur. 


\section{GENiș ÖZET}

Öz düzenleyici öğrenme, etkin ve yapıcı bir süreç olup, bu süreçte öğrenenlerin hedef belirlemesi, bu hedeflerin doğrultusunda kendi biliş düzeylerini, motivasyon ve davranışlarını, izlemesi, düzenlemesi ve denetlemesidir (Pintrich, 2000).Kapsamlı öz düzenleme, öğrenenlerin bilişsel, üstbilişsel ve motivasyon stratejilerini kullanması ile mümkün olmaktadır (Leutwyler, 2009).Bunların arasında, üstbilişsel stratejiler üst düzey idari süreçler olup, öğrencilere kendi öğrenme süreçlerini kontrol etmede, planlamada, izlemede ve düzenlemede yardımcı olur (Gall, Gall, Jacobsen, \& Bullock, 1990).Üstbilişsel stratejilerin öğrenciler tarafından kullanılması için motive edilmesi gerekmektedir (Pintrich, 1988).

Son yıllarda motivasyon öğesi olan başarı hedef yönelimleri ile yapılan çalışmalar hız kazanmıştır.Başarı hedef yönelimleri, başarılı olmak istemenin nedenleri ve verilen görevlere nasıl yaklaşıldığı ile alakalıdır (Pintrich, 2000).Bu başarı hedef yönelimleri dört gruba ayrılmaktadır.Bunlar Ustalık yaklaşım, ustalık kaçınma, başarım-yaklaşım ve başarım-kaçınma hedef yönelimleridir.Ustalık-yaklaşım hedef yönelimleri ile öğrenmek, bir konuda ustalaşmak yeni beceriler geliştirmek ile alalıdır Diğerlerinin nasıl bir performans sergilediği ile ilgilenmez (Dweck \& Leggett, 1988; Maehr \& Midgley, 1991; Nicholls, 1984). Bunun yanında, ustalık-kaçınma ise öğrenmeden kaçınma, ya da göstereceğinden daha az çaba sarf etme olarak tanımlanmaktadır (Pintrich \& Schunk, 2002). Başarım hedef yönelimleri, ustalık hedef yönelimlerin aksine sosyal karşılaştırmaya önem vermesi ve diğerlerini referans alarak performans göstermesi olarak belirtilir (Dweck \& Leggett, 1998; Midgley et al., 1998).Ustalık hedef yönelimleri gibi ikiye ayrılmaktadır.Başarım-kaçınma hedef yönelimlerinde öğrenciler grupta en iyi olmak için mücadele ederken, başarım-kaçınmada yeteneksiz görünmekten kaçınmak için çalışmaktadır (Pintrich \& Schunk, 2002). Yapılan çalışmalar ustalık hedef yönelimlerinin derin bilişsel strateji kullanma, göreve ilgi duyma, başarıyı isteme ve zor durumlar karşısında azimli olma gibi değişkenlerle pozitif ilişkili olduğunu gösterirken, başarım hedef yönelimleri yüzeysel bilişsel stratejiler kullanma, gerekli çaba göstermeme gibi değişkenlerle pozitif ilişki rastlanmıştır (Pintrich, 2000; Wolters, Yu \& Pintrich, 1996).

Öğrenme süreçlerinin ve sonuçların anlamada kişisel ilgi de önemli bir motivasyon öğesi olarak görülmektedir.Kişisel ilgi bireylerin öğrenme, düşünme ve performanslarına büyük katk1 sağlamaktadır (Pintrich \& Schunk, 2002). Özellikle, kişisel ilginin, öğrencilerde bilgilerin kalıcılığını sağlamada, görev tamamlamada ve başarıya ulaşmada önemli bir etki yaptığı görülmüştür (Renninger \& Hidi, 2002; Singh, Granville \& Dika, 2002; Xu, 2008).

Milli Eğitim Bakanlığına (2006) göre fen eğitiminin amacı yaşam boyu öğrenmeyi gerçekleştiren bireyler yetirmektir.Bu bağlamda, öğrencilerin öğrenme sürecinde aktif olması, bilgi alımı ve bilginin yapılandırmasında özdüzenleme becerisinin kazandırılması amaçlanmıştır.Öz düzenleme bir beceri olup, öğretmenler tarafından öğrencilere kazandırılması gerekmektedir.Fakat öğrenciye kazandırmak için öğretmenlerin kendi öğrenme ortamında öz düzenlemeyi tecrübe etmesi gerekmektedir.Dolayısıyla, fen bilgisi öğretmen adaylarının bu öz düzenleme ve öz düzenlemenin boyutları konusunda araştırılması gerekmektedir.

Başarı hedef yönelimi ve kişisel ilgi ile yapılan çalışmalar öğrenme strateji kullanımı ile pozitif bir ilişkide olduğunu göstermiştir.Örneğin, Butler (2007) başarı hedef yönelimlerinin öğrenme için bir çerçeve sunduğunu, öğrenme stratejilerinin öğrenme için geliştirilen hedeflerle yakından ilgili olduğunu söylemiştir. Bunun yanımda, Schiefele (1991) kişisel ilgi ile detaylandırma, eleştirel düşünme gibi derin bilişsel stratejilerin kullanılmasında bir pozitif ilişki olduğunu belirtmiştir.

Alanyazında, öğretmen adaylarının öğrenme stratejileri kullanımının, başarı hedef yönelimleri ve kişisel ilgi ile ilişkisini açıklayan yeterli çalışma yoktur.Öğrencilerde olduğu gibi başarı hedef yönelimleri ve kişisel ilginin öğretmen adaylarının öğrenme stratejilerin kullanımı konusunda bir ilişkisi olabileceği düşünülmektedir.Bu çerçevede, bu çalışmanın amacı fen bilgisi öğretmen adaylarının başarı hedefi yönelimleri ve kişisel ilgilerinin bilişüstü strateji kullanımını yordamadaki katkısını belirlemektir.Bu çalışmaya; öğrenme stratejisi olarak, daha yüksek düzeyde işlemler gerektiren bilişüstü öğrenme stratejileri dahil edilmiştir.

$\mathrm{Bu}$ çalışma, ilköğretim fen bilgisi eğitimi programında okuyan 322 fen bilgisi öğretmen adayı ile yürütülmüştür. Bu katılımcıların 96's1 erkek, 226's1 ise kız olup, \% 37.3 birinci sınıfta, \% 26.5 ikinici, \% 24.5 üçüncü sınıfa ve \% 11.8 dördüncü sınıfa gitmektedir. Veriler, "Öğrenmede Güdüsel Stratejiler Ölçeğinin, Bilişüstü Özdüzenleme Alt Ölçeğì", "Başarı Hedefleri Anketi” ve "Akademik İlgi Anketi” 
kullanarak toplanmıştır. Bilişüstü özdüzenleme alt ölçeği 12 madde ve bir faktörden oluşan 7’li likert tipi öz bildirime dayalı bir ölçme aracıdır.Başarı hedefler anketi ise 15 madde ve dört faktörden oluşan 5'li bir likert bir yapıya sahipken, akademik ilgi anketi 6 maddeden 5'li likerte dayalı bir ölçektir.Güvenirlik ve geçerlilik açısından, veriler kontrol edilmiştir.Bu veriler hiyerarşik regresyon ile analiz edilmiştir.Regresyon analizine geçmeden önce, varsayımlar kontrol edilmiştir.Normallik, doğrusallık, eşvaryanslılık ve eşdoğrusallık açısından herhangi bir sakınca görülmemiştir.Bu sonuçtan sonra, hiyerarşik regresyon aşamasına geçilmiştir. Yapılan analiz sonucunda, başarı hedef yönelimleri ile kişisel ilgi değişkenlerinin üstbilişsel strateji kullanımının \% 33.6' lık kısmını açıkladığı bulunmuştur, $R=.58, F(5,96)=9.70, p<.05$. Ayrıca, ustalık-yaklaşım hedef yöneliminin, bilişüstü strateji kullanımını önemli ölçüde istatiksel olarak yordadığ görülmüştür $\mathrm{p}<.05 . \% 36^{\prime}$ lık varyansın içinde \% 4 kısmın, ustalık-yaklaşım hedef yöneliminin açıkladığı belirlenmiştir.Bunun yanında, ustalık-kaçınma hedef yöneliminin, başarım-yaklaşım hedef yönelimi, başarım-kaçınma hedef yönelimi ve kişisel ilgilerin bilişüstü strateji kullanımı önemli ölçüde tahmin etmediği görülmüştür. $\mathrm{Bu}$ çalışmanın sonuçları, üniversite hocaları, araştırmacılar ve program hazırlayıcılar için bir bilgilendirme niteliğindedir. Fen öğretimini planlarken, başarı hedef yönelimlerinin üstbilişsel strateji kullanımı ile ilgili olduğu göz önünde bulundurmalı, güdüleyici ve üstbilişsel strateji kullanımı içeren aktiviteler hazırlanmalıdır.

$\mathrm{Bu}$ çalışma için küçük bir örneklemden bir veri toplanmıştır.Dolayısıyla, daha güvenilir sonuçlara ulaşmak için daha büyük örneklemden veri toplanmalıdır.Ayrıca, gelecek çalışmalara sosyoekonomik düzeyi, etnik köken, bireylerin ön bilgisi, başarı düzeyleri ve cinsiyet gibi bireysel faktörlerin katılmasının daha güvenilir sonuçların elde edilmesinde önemli olduğu söylenilmektedir.Diğer yandan, fen bilgisi öğretmen adaylarının anketlere cevap verirken, yanlı cevap vermiş olasıllğı olduğundan, bu çalışmanın sonuçları doğrulaması açısından bu alanda yapılacak çalışmalara ihtiyaç vardır.Son olarak, bu çalışma değişkenler arasında nedensellik ilişkisi sağlamadığı için deneysel çalışmalara yürütülmelidir. 


\section{INTRODUCTION}

Self-regulated learning is defined as "it is an active, constructive process whereby learners set goals for their learning and then attempt to monitor, regulate and control their cognition, motivation and behavior, guided and constrained by their goals and the contextual features in the environment" (Pintrich, 2000, p.453). Based on this terminology, Pintrich (2000) proposed general framework for self-regulated learning which is composed of four phases; forethought, monitoring, controlling and reflection phases. In the forethought phase, self-regulation activities which are goal setting, prior content knowledge activation, metacognitive knowledge activation, efficacy judgments, time and effort planning, and perceptions of task are involved. The monitoring phase is related to metacognitive awareness of different aspects of self and task or context. The control phase includes selection and adaptation of cognitive strategies for learning, thinking, motivation and affect, and regulation of effort, task, and context. The reflection phase involves cognitive judgments, affective reactions, making choices, and evaluations of the task.

Leutwyler (2009) stated that comprehensive self-regulated learning only becomes possible when the learner possesses a repertoire of strategies which includes cognitive, metacognitive and motivational. Among these strategies, cognitive and metacognitive strategies are cornerstone of self-regulated learning (Somuncuoglu \& Yildirim, 1999). Cognitive strategies include rehearsal, elaboration, organization, and critical thinking strategies to help learner encode, organize and retrieve new information (Schraw, Crippen \& Hartley, 2006). On the other hand, metacognitive strategies are high level administrative processes which provide learners to control and manage their learning processes including planning, monitoring, and regulating (Gall, Gall, Jacobsen, \& Bullock, 1990). There are two subcomponents of metacognitive strategies which are knowledge of cognition and regulation of cognition (Schraw \& Moshman, 1995). Knowledge of cognition refers to what individuals know about their cognition and involve three subcomponents. According to Schraw et al. (2006), declarative knowledge is composed of knowledge about learners' their performance and factors which have influence on their performance. Procedural knowledge includes knowledge about strategies and other procedures to learn a task. Finally, conditional knowledge refer to knowledge of why and when to use a particular strategy. Alexander, Carr and Schwanenflugel (1995); Baird and White (1996) declared that individuals have knowledge of cognition which is late developing and explicit. Therefore, adults have more knowledge about their own cognition and can describe knowledge better than children and adolescents. Regulation of cognition is composed of three components, planning, monitoring, and evaluation. Schraw et al. (2006) stated that planning is related to appropriate strategies and the usage of resources, including goal setting, activating relevant background knowledge, and budgeting time. Monitoring means controlling learning by the self-testing skills. Evaluation includes appraising the products and regulatory processes of learning. Research on regulation cognition indicates that these processes happen automatically in especially adult learner. This is because they might not be conscious and explicit in learning environments (Butler \& Winne, 1995).

Despite importance of cognitive and metacognitive strategies for student learning, Pintrich (1988) claimed that students also should be motivated to use these strategies and regulate their cognition and effort. Therefore, motivational self-regualtion also plays a central role in an integrated model of selfregulated learning (Pintrich \& De Groot, 1990). Motivational self-regulation is conceptualized as including all those attitudes, abilities, and motivational factors that have the objective of facilitating learning, sustaining effort and attention, and enabling completion of activities, such as self-esteem, self-efficacy beliefs, outcome expectancy, interest and goal orientation (Deci \& Ryan, 1985; Dweck \& Elliott, 1983).Garcia \& Pintrich, 1994; Sungur \& Tekkaya, 2006).

One of these motivational factors is goal orientation. According to socio-cognitive theories of motivation, a pursuing goal influences in interpreting and responding to events, producing associated patterns of cognition, affect, and behavior (Dweck \& Leggett, 1988). This premise has made the type of academic goals that a student pursues as one of the most important variables in motivational research in educational contexts (Poondej, Koul \& Sujivorakul, 2013). Motivational goals have been defined in the literature as achievement goal orientation which is general orientation to the task that includes a number of related beliefs about purposes for doing the task, competence, success, ability, effort, and standards to evaluate task performance (Pintrich, 2000). In other words, goal orientations are concerned with why individuals want to success and how they approach and engage in the task.In 
related literature, goal orientation is divided into two categories and they are labeled differently such as learning and performance goals (Elliot \& Dweck, 1988; Miller, Behrens, Greene \& Newman, 1993); task and ego goals (Fox, Goudes, Biddle, Duda \& Armstrong, 1994); mastery and performance (Ames \& Archer, 1988); and task-focused and ability-focused goals (Maehr \& Midgley, 1991). Although there are disagreement among researchers in terms of labeling, mastery and performance goals terms have been used in many researches to differentiate two general goal orientations. Mastery goal orientation is related to learning, mastering the task, developing new skills, trying to gain understanding or insight (Dweck \& Leggett, 1988; Maehr \& Midgley, 1991; Nicholls, 1984). Being mastery goal oriented is related to adaptive perceptions and behaviors including use of learning strategies (Ho \& Hau, 2008; Somuncuoğlu \& Y1ldırım, 1999). In contrast, performance goal orientation is concerned with demonstrating competence or ability and being best compared to others, (Dweck \& Leggett, 1998; Midgley et al., 1998). Learners with performance goals show maladaptive perceptions and behaviors such as using less learning strategies (Somuncuoğlu \& Y1ldırım, 1999). Increase in research on goal orientation showed that mastery goal orientation and performance goal orientation can be related to both adaptive and maladaptive behaviors (Bulus, 2011). Therefore, these goal orientations are examined in terms of approaching goals or avoiding goals. From this perspective, four type goal orientations were synthesized. According to Pintrich and Schunk (2002), mastery approach goal orientation focuses on understanding, learning task while mastery avoidance goal orientation is associated with tendencies to avoid work and minimizing effort. Performance approach goal orientation is related to being best in group or doing task best in comparison to other people. Performance avoidance goal orientation focuses on not looking dumb and stupid compared to other people (Pintrich \& Schunk, 2002). Research stated that while student who are performanceapproach oriented demonstrate adaptive behaviors such as use of learning strategies (Pintrich, 2000; Wolters, Yu \& Pintrich, 1996), performance-avoidance oriented student show negative outcomes in use of learning strategies and achievement (Elliot \& Church, 1997). Mastery-avoidance goal oriented students showed negative outcomes such as not applying learning strategies to new task to learn (Elliot, 1999).

During the past two decades, interest has also become another important motivational construct for understanding the processes and outcomes of learning (Leibham, Alexander \& Johnson, 2013). According to Krapp, Hidi and Renninger (1992), there are three perspectives in interest research. Personal interest refers to characteristic of individual which is stable, enduring disposition of individual. Personal enjoyment, personal importance of topic, preference for certain topics and general liking for special field constitute cornerstone of personal interest (Schiefele, Krapp \& Winteler, 1992). Situational interest is another perspective in research studies which is relate to interestingness of the content such as novelty, surprise, and complexity while interest as psychological state is generated by interaction between personal interest and interesting environmental features. Among these interest perspectives, personal interest demonstrates individual differences in terms of learning, thinking and performance (Pintrich \& Schunk, 2002). Specifically, personal interest has led to desirable outcomes in children including persistence (Renninger \& Hidi, 2002), task completion (Xu, 2008), and achievement (Singh, Granville \& Dika, 2002). Likewise, interest towards science plays an important role in science learning and choosing science-related careers (Tai, Liu, Maltese \& Fan, 2006).

In the literature, some studies were conducted to explore relationship among self-regulation, goal orientations and interest. For example, Iverach and Fisher (2008) reported that while mastery approach and performance avoidance goals were positively related to self-regulation, while the mastery avoidance and performance approach goals were negatively related to self-regulation. In same vein, Bembenutty (2012) did a research with preservice teachers and found that having a mastery-goal orientation is positively associated with self-regulation. In meta-analysis of Cellar et al. (2011), it was also found that the mastery-approach goal orientation construct was positively related to the selfregulation. Conversely, negative relationships were reported between the performance-avoidance goal orientation and self- regulation. Concerning interest, Pintrich and De Groot (1990); Pintrich, Roeser, and De Groot (1993); Iverach and Fisher (2008) found that there are significantly positive relationship between interest and self-regulation. Likewise, Sansone \& Thoman (2005); Lee, Lee and Bong (2014) reported that interest is the strong predictor of academic self-regulation. In addition, O'Keefe and Garcia (2014) pointed out that undergraduate students with high interest to task show better selfregulation behavior. 


\section{The Statement of Problem}

The primary goal of science education is to develop students as life-long learners, help students to be active in learning process and self-regulate their acquisition and construction of knowledge (Ministry of National Education of Turkey [MONE], 2006). Arsal (2009) emphasized that it is important for teachers to help students to become self-regulated learner. The affective way to teach of selfregulation is to experience self-regulation in their learning environments. For this purpose, Taylor and Corrigan (2005) claimed that providing pre-service science teachers with suitable self-regulated learning environments contributes to development of their future students' self-regulation and science learning. Development of self-regulated learning depends on use of learning strategies (Akyol, Sungur, \& Tekkaya, 2010). Therefore, it is important to investigate preservice science teachers with respect to use of learning strategies.

As similar to studies related to self-regulation, research showed that using learning strategy is related to goal orientation and interest. For example, Butler (2007) claimed that goal orientation presents useful framework for individuals motive for learning since individuals' perception, learning strategies and outcome depend on what they want. Clercq, Galand and Frenay (2013) found that mastery goal orientation is significant predictor of using deep processing strategies. In the same vein, Kahraman and Sungur (2011) conducted a study with elementary students to examine how goal orientation predicts metacognitive strategy use. They found similar result that mastery approach goals tend to use metacognitive strategies in science. In addition, Ee, Moore, and Atputhasamy (2003); Pintrich and De Groot, (1990); Tung-hsien (2004); Valle et al., (2003); and Wolters, Yu, and Pintrich, (1996) stated that mastery goals are associated with higher levels of metacognitive strategy use. Regarding interest, it was found that interest is one of influential factor on using students' learning strategies. For instance, Pintrich and Garcia (1991), and Schiefele (1991) reported that interest of college students and junior students is positively related with deep processing strategies such as organization critical thinking, and elaboration. Likewise, Wigfield and Eccles (2000) pointed out that students having an intrinsic interest enable to persist in overcoming difficulties and succeed on academic tasks by using metacognitive strategies.

In the literature, there is no sufficient research concerning investigating the contribution of both goal orientation and interest in use of metacognitive strategies studies. Moreover, in Turkey metacognitive strategy use, goal orientation, and interest were investigated in terms of different variables such as achievement, competence expectancy, perception, and self-efficacy(e.g. Akyol, Sungur \& Tekkaya, 2010; Bulus, Duru, Balkis, \& Duru, 2011; Sungur, 2007; Sungur \& Senler, 2009, 2010). However, relationship among these three constructs, which are metacognitive strategy use, goal orientation, and interest was examined in few research. Hence, the aim of this study aimed to determine role of preservice science teachers' achievement goal orientations and personal interest in prediction of metacognitive strategy use. Accordingly, this study aimed at addressing the following research question:

What is the contribution of achievement goal orientation and personal interest in prediction of metacognitive strategy of preservice science teacher?

\section{METHOD}

\section{Sample}

The participants of this study were 322 preservice science teachers ( 96 boys and 226 girls, mean age $=$ 21.54 and $S D=1.65$ ) from one public university in Ankara, Turkey. Among these preservice teachers, $37.3 \%$ was freshman, $26.5 \%$ was sophomore, $24.5 \%$ was junior and $11.8 \%$ was senior in this university. The mean and standard deviation of preservice science teacher' GPA were 2.33 and .52, respectively. While $7.8 \%$ preservice science students was member any club or organization concerning science, $92.2 \%$ of them declared that they were not member of a science club or organization. Moreover, they were asked to how many books or journal related science they have. $40.2 \%$ of the preservice science teachers had books or journal ranged from 0 to $10.30 .4 \%$ of them stated that number of science books or journal was between 11 and $25.19 .6 \%$ these teachers reported to have 2650 . $8.8 \%$ of preservice science teacher indicated that they possessed nearly more than 50 science books or journal. 


\section{Instruments}

Motivated Strategies for Learning Questionnaire (MSLQ)

The Motivated Strategies for Learning Questionnaire (MSLQ) developed by Pintrich, Smith, Garcia, and McKeachie (1991) was translated and adapted into Turkish by Sungur (2004). This scale consisted of two sections which were the motivation section (31 items) and the learning strategies section (50 items). The items were scored on a 7-point Likert-type scale from 1 (not at all true for me) to 7 (very true for me). 31 items of the MSLQ related to students' use of several cognitive and metacognitive strategies in learning strategies section part were used for the subject area "science". The items were categorized into five subscales: rehearsal ( 4 items, $\alpha=.65$ ), elaboration ( 6 items, $\alpha=.76$ ), organization (4 items, $\alpha=.59$ ), critical thinking ( 5 items, $\alpha=.72$ ), and metacognitive self-regulation (12 items, $\alpha=$ .80 ). In this study, only metacognitive self-regulation subscale was used to measure of metacognitive strategy use. Reliability coefficient of this subscale was founded .82 which was nearly same with result of study of Sungur (2004). In addition, this metacognitive self-regulation subscale was examined in terms of structural validity by confirmatory factor analysis. According to Kline (2005), there are four fit indices which are the $\chi^{2} / \mathrm{df}$ ratio, the Tucker-Lewis index (TLI), the comparative-fitindex (CFI), and the root mean squared error of approximation (RMSEA). A good fit is indicated when $\chi^{2} / \mathrm{df}<3.00$; TLI and CFI $>.90$, and RMSEA $<.08$. The result of confirmatory factor analysis showed good fit $\left(\chi^{2} / \mathrm{df}=2.38, \mathrm{TFI}=.93, \mathrm{CFI}=.98\right.$ and $\left.\mathrm{RMSEA}=.04\right)$.

Achievement Goals Questionnaire (AGQ)

The achievement goal questionnaire scale was developed by Elliot and Mcgregor (2001) to determine achievement goals of student. It translated and adapted into Turkish by Senler \& Sungur (2007). It was comprised of 15 items in four subscales which are mastery-approach goals ( 3 items), masteryavoidance goals ( 3 items), performance-approach goals ( 3 items) and performance avoidance goals (6 items). The items were scored on a 5-point Likert-scale ranging from strongly agree to strongly disagree. After collecting of data, reliability of coefficients was examined for each dimension, mastery-approach goals $(\alpha=.73)$, mastery-avoidance goals $(\alpha=.75)$, performance-approach goals $(\alpha=$ .86) and performance avoidance goals $(\alpha=.82)$. In addition, in terms of structural validity, confirmatory factor analysis showed that it have adequate fit $\left(\chi^{2} / \mathrm{df}=5.82, \mathrm{TFI}=0.95, \mathrm{CFI}=.95\right.$ and RMSEA = .07).

The Academic Interest Questionnaire (AIQ)

The academic interest questionnaire was developed by Corbiere, Fraccaroli, Mbekou, \& Perron (2006) to assess students' interest in science. It was translated and adapted into Turkish by Senler and Sungur (2009). It consisted of 6 items and these items were scored on 5 point-Likert type scales ranging from completely agree to completely disagree. Reliability coefficient of data of this scale was .83 which was higher to result of study ( $\alpha=.71)$ of Senler and Sungur (2009). Moreover, confirmatory factor analysis showed that it have good fit $\left(\chi^{2} / \mathrm{df}=3.12 \mathrm{TFI}=.97, \mathrm{CFI}=.95\right.$ and RMSEA $\left.=.05\right)$.

\section{Data Analysis Procedure}

In this study, in order to find out how well goal orientations and personal interest is able to predict metacognitive strategy use, multiple regression analysis was conducted. Multiple regression is a technique which allows to explore prediction of dependent variable based on two or more independent variables related to dependent variable (Pallant, 2007). Before conducting this analysis, assumptions of multiple regression which are normality, linearity, multicollinearity, and homoscedasticity was also checked to reach reliable results.

\section{RESULTS}

In order to address the research question, multiple regression analysis was performed. Before that, preliminary analyses were conducted to ensure no violation of the assumptions of normality, linearity, multicollinearity, and homoscedasticity. Especially, multicollinearity was examined in detail to reach reliable results. According to Pallant (2007), multicollinearity does not exist when the correlation between variables should be less than .07, tolerance value are higher than .10 and VIF values are less than 10. These correlations and values are presented Table 1 and Table 2. As can be seen below, there is no violation of multicollinearity. 
Table 1: Correlations between Variables

\begin{tabular}{|c|c|c|c|c|c|c|}
\hline Variables & 1 & 2 & 3 & 4 & 5 & 6 \\
\hline 1.Mastery approach goal orientation & 1 & .46 & .14 & .31 & .58 & .51 \\
\hline 2.Performance approach goal orientation & & 1 & .25 & .18 & .23 & .33 \\
\hline 3.Mastery avoidance goal orientation & & & 1 & .12 & .44 & .34 \\
\hline 4.Performance avoidance goal orientation & & & & 1 & .12 & .32 \\
\hline 5.Personal interest & & & & & 1 & .47 \\
\hline 6. Metacognitive strategy use & & & & & & 1 \\
\hline
\end{tabular}

Table 2: Tolerance and VIF Values of Variables

\begin{tabular}{lcc}
\hline Variables & Tolerance & VIF \\
\hline Mastery approach goal orientation & .54 & 1.87 \\
Performance approach goal orientation & .49 & 2.05 \\
Mastery avoidance goal orientation & .67 & 1.49 \\
Performance avoidance goal orientation & .46 & 2.16 \\
Personal interest & .54 & 1.84 \\
\hline
\end{tabular}

The results of main analysis indicate that these motivational factors accounted for $33.6 \%$ of the variation in preservice science teachers' metacognitive strategy use, $R=.58, F(5,96)=9.70, p<.05$. More specifically, it is found that mastery approach goal orientation made significantly contribution to prediction of metacognitive strategy use $(p<.05)$ while mastery avoidance goal, performance approach, performance avoidance goal orientations and personal interest failed to reach significance. Mastery approach goal orientation (Beta $=.28$, sr-squared $=.04$ ) was statistically significantly predicted preservice science teachers' metacognitive strategy use in science courses. Sr-squared represented that $4 \%$ variance is explained by only mastery approach goal orientation over $33.6 \%$ variance in preservice science teachers' metacognitive strategy use, The Beta coefficients, values of sr-squared and related significance values were presented in Table 3.

Table 3: Contribution of Motivational Factors on Metacognitive Strategy Use

\begin{tabular}{lccc}
\hline Motivational factors & Beta & Sr-squared & $\mathrm{p}$ \\
\hline Mastery approach goal orientation & .28 & .04 & .01 \\
Performance approach goal orientation & .18 & .03 & .14 \\
Mastery avoidance goal orientation & .20 & .02 & .06 \\
Performance avoidance goal orientation & -.24 & .03 & .06 \\
Personal interest & .19 & .03 & .10 \\
\hline
\end{tabular}

\section{DISCUSSION and IMPLICATION}

This research aimed to examine role of achievement goals and personal interest of preservice science teachers on prediction of metacognitive strategies use. For this purpose, multiple regression analysis was conducted. It was found that only mastery approach goal orientation among these motivational factors made a significantly contribution to prediction of preservice science teachers' metacognitive strategy use in science course. This result was in congruence with finding conducted among students in the literature (Clercq, Galand, \& Frenay, 2013; Ee, Moore, and Atputhasamy, 2003; Kahraman, \& Sungur, 2011; Pintrich and De Groot, 1990; Tung-hsien, 2004; Valle et al., 2003; and Wolters, Yu, \& Pintrich, 1996). This finding may imply that these preservice teacher want to become efficient teacher; therefore, they work in the light of this aim. As a second result, it was found that the contribution of performance approach goals to use of metacognitive strategies was not statistically significant. This finding was in contradiction with finding of researchers concerning students (Pintrich, 2000; Wolters et al., 1999). This result may be caused by Turkish educational system. Senler and Sungur (2009) declared that Turkish students are educated competitive and examination oriented. Especially, after they graduate high school, they take highly competitive examination to enter university. Therefore, this situation may influence negatively and make them show less competitive behaviors in university courses. Another result in this study was related to mastery avoidance goal orientation. In related literature, Elliot (1999) founded that individuals avoided trying tasks and activities in mastery avoidance goal orientation. Based on finding of studies of Iverach and Fisher (2008); Cellar et al. (2011), it was expected that higher levels of mastery avoidance goal orientation were associated with 
lower level use of metacognitive strategies, However, it was found that mastery avoidance goal orientation did not predict statistically metacognitive strategy use of preservice science students. The reason of this result may be due the fact that preservice science teachers know they are responsible for learning of science teaching; therefore, they do not show avoidance about trying task or activities. Concerning performance avoidance goal orientation, this study revealed that there was no a significant contribution to prediction of preservice science teachers' metacognitive strategy use in science courses. The finding of this study was contradiction with finding of researchers which was that performance avoidance goal orientation was related to use less metacognitive strategy (Elliot \& Church, 1997). The reason of this research finding can be related to inapplicability of this goal orientation for preservice teachers. More specifically, prior studies related to this goal orientations were conducted with students. Therefore, preservice teachers may not find this goal orientation meaningful since the focus of this orientation is to avoid looking dumb in comparison others (Pintrich \& Schunk, 2002). Lastly, concerning the contribution of personal interest to science, it was expected that personal interest predict significantly in terms of statistical to use of metacognitive strategies in science course since Pintrich and Garcia (1991); Schiefele (1991), and Wigfield and Eccles (2000) reported that having interest to a task was positively associated with use of metacognitive strategy. However, in this study it was found that interest did not make significantly contribution to prediction of preservice science teachers' metacognitive strategy use in science course. The role of other motivational factors which were not examined in this study may lead to occurrence of this finding. According to Sungur \& Tekkaya (2006), self-efficacy belief, task value, outcome expectancy are other motivational factors that influence self-regulation process. Since these factors were not controlled in the analysis, this finding that interest did not significantly predict use of metacognitive strategies may be found.

The results of this study would be informing for university teachers, researchers and policy makers; when planning science instruction, they would be aware of the fact that motivational factors would be related to using learning strategies and they would use motivational factors and learning strategies together in science lesson.

\section{LIMITATIONS and FUTURE DIRECTIONS}

In this study, data was gathered from small sample in a state college. Therefore, in order to reach more reliable results, future researches should include more participants. Another limitation of this study is that there are other factors which have influence on metacognitive strategy use of preservice teacher. Teacher background variables (SES, ethnicity, past performance, prior knowledge, gender) also affect metacognitive strategy use (Akyol, Sungur \& Tekkaya, 2010). Therefore, it is suggested that in future studies these factors should be examined with motivational factors to learn inclusion of background variables into these motivational variables.

In addition, there may be possibility of social desirability in preservice science teachers' responses in these scales in this study. Therefore, future studies are needed to validate the results of this study. Also, this study does not provide causal relationship among these variables. In order to reach causal relationship about them, experimental studies should be conducted.

\section{REFERENCES}

Akyol, G., Sungur, S., \& Tekkaya, C. (2010). The contribution of cognitive and metacognitive strategy use to students' science achievement.Educational Research and Evaluation, 16(1), 1-21.

Alexander, J. M., Carr, M., \& Schwanenflugel, P. J. (1995). Development of metacognition in gifted children: Directions for future research. DevelopmentalReview, 15(1), 1-37.

Ames, C., \& Archer, J. (1988). Achievement goals in the classroom: Student learning strategies and motivation processes. Journalof Educational Psychology, 80, 260-267.

Arsal, Z. (2009).The effects of diaries on self-regulation strategies of preservice science teachers. International Journal of Environmental \& Science Education, 5(1), 85-103.

Baird, J. R., \& White, R. T. (1996).Metacognitive strategies in the classroom. In D. F. Treagust, R. Duit, \& B. J. Fraser (Eds.), Improving teaching and learningin science and mathematics (pp. 190-200). New York: Teachers College Press.

Bembenutty, H. (2012). A latent class analysis of teacher candidates' goal orientation, perception of classroom structure, motivation, and self-regulation.Psychology Journal, 9(3).97-106. 
Bulus M. (2011). Goal orientations, locus of control and academic achievement in prospective teachers: An individual differences perspective. Educational Sciences: Theory \& Practice, 11(2), 540-546.

Bulus.M., Duru, E., Balkıs, M., \& Duru, S. (2011).The role of learning strategies and individual characteristics in predicting academic achievement in prospective teachers.Education and Science, 36(161),186-198.

Butler, D. L., \& Winne, P. H. (1995). Feedback and self-regulated learning: A theoretical synthesis. Review of Educational Research, 65(3), 245-281.

Butler, R. (2007). Teachers' achievement goals and associations with teachers' help-seeking: Examination of a novel approach to teacher motivation. Journal of Educational Psychology, 99, 241-252.

Cellar, D. F., Stuhlmacher, A. F., Young, S. K., Fisher, D. M., Adair, C. K., Haynes, S.....Riester, D. (2011). Trait goal orientation, self-regulation, and performance: A meta-analysis. Journal of Business and Psychology, 26(4), 467-483.

Clercq, M. D.,Galand, B., \& Frenay, M. (2013). Chicken or the egg: Longitudinal analysis of the causal dilemma between goal orientation, self-regulation and cognitive processing strategies in higher education. Studies in Educational Evaluation, 39, 4-13.

Corbiere, M., Fraccaroli, F., Mbekou, V., \& Perron, J. (2006). Academic self-concept and academic interest measurement: A multi-sample European study. European Journal of Psychologyof Education, 21, 3-15.

Deci, E. L., \& Ryan, R. (1985).Intrinsic motivation and self-determination in human behavior. New York: Plenum.

Dweck, C. S., \& Elliott, E. S. (1983).Achievement motivation. In P. H. Mussen (Ed.), Handbook of child psychology: Socialization, personality, and social development (vol. (Vol. IV)). New York: John Wiley \& Sons.

Dweck, C. S., \& Leggett, E. L. (1988).A social cognitive approach to motivation and personality.Psychological Review, 95, 256-273.

Ee, J., Moore, P. J., \& Atputhasamy, L. (2003). High achieving students: Their motivational goals, selfregulation and achievement and relationship to their teachers' goal and strategy-based instruction. High Ability Studies, 14, 23-39.

Elliot, A. J. (1999). Approach and avoidance motivaiton and achievement goals.Educational Psychologist, 34, 169-189.

Elliot A. J., \& Church, M. A. (1997).A hierarchical model of approach and avoidance achievement motivation.Journal of Personalityand Social Psychology, 72, 218-232.

Elliot, A. J., \& Mcgregor, H. A. (2001).A 2x2 achievement goal framework.Journal of Personality and Social Psychology, 80, 501-519.

Elliot, E. S., \& Dweck, C. S. (1988). Goals: An approach to motivation and achievement. Journal of Personality \& Social Psychology, 54, 5-12.

Fox, K., Goudas M., Biddle, S., Duda, J., \& Armstrong, N. (1994). Children's task and ego goal profiles in sport. British Journalof Educational Psychology, 64, 253-261.

Gall, M. D., Gall, J. P., Jacobsen, D. R., \& Bullock, T. L. (1990).Tools for learning. Alexandria, VA: Association for Supervision and CurriculumDevelopment.

Garcia, T., \& Pintrich, P. R. (1994).Regulating motivation and cognition in the classroom: The role of selfschemas and self-regulatory strategies.In D. H. Schunk, \& B. J. Zimmerman (Eds.), Self regulation of learning and performance.issues and educational applications (pp. 127-153). Hillsdale: Lawrence Erlbaum Associates..

Ho, I. T., \& Hau, K. T. (2008). Academic achievement in the Chinese context: The role of goals, strategies, and effort. InternationalJournal of Psychology, 43(5), 892-897.

Iverach, M.R. \& Fisher, D.L. (2008). An interdisciplinary investigation of high schools' approaches to learning sciences: The relations amongst achievement goals, constructivist pedagogical dimensions, motivational beliefs and self-regulated learning. Proceedings of the Fifth International Conference on Science, Mathematics and Technology Education, 233-255.

Kahraman, N., \& Sungur S. (2011).The contribution of motivational beliefs to students' metacognitive strategy use.Education and Science, 36(160), 3-10.

Kline, R. B. (2005). Principles and practices of structural equations modeling. New York, NY: Guilford.

Krapp, A., Hidi, S., \& Renninger, K. A. (1992).Interest, learning and development. In K. A. Renninger, S. Hidi, \& A. Krapp (Eds.), The role of interest in learning and development (pp. 3-25). Hillsdale, NJ: Erlbaum.

Lee, W., Lee, M. J., \& Bong, M. (2014).Testing interest and self-efficacy as predictors of academic selfregulation and achievement.Contemporary Educational Psychology, 39, 86-99.

Leibham, M. B., Alexander, J. M., \& Johnson, K. E. (2013).Science interests in preschool boys and girls: Relations to later self-concept and science achievement.Science Education, 97(4), 574-593.

Leutwyler, B. (2009). Metacognitive learning strategies: Differential development patterns in high school, Metacognition Learning, 4, 111-123. 
Maehr, M. L., \& Midgley, C. (1991).Enhancing studnets motivation: A schoolwide approach.Educational Psychologist, 26, 339-427.

Midgley, C., Kaplan, A., Middleton, M., Maehr, M., Urdan T., Hicks A. L., Anderman, E., \& Rooser, R. (1998).The development and validation of scales assessing students' achievement goal orientations. Contemporary educational Psychology, 23, 113-131.

Miller, R. B., Behrens, J. T., Greene, B. A., \& Newman, D. (1993). Goals and perceived ability: Impact on student valuing, self-regulation and persistence. Contemporary Educational Psychology, 18, 2-14.

Ministry of National Education of Turkey. (2006). Science and technology curriculum of elementary schools (6th-8th grades) [in Turkish].Board ofEducation.

Nicholls, J. (1984). Achievement motivation: Conceptions of ability, subjective experience, task choice and performance. Psychological Review, 91, 328-346.

Pintrich, P. R. (1988). A process-oriented view of student motivation and cognition.In J. S. Stark \& L. Mets (Eds.), Improving teaching and learning through research.New directions for institutionalresearch, 57(pp. 55-70). San Francisco: Jossey-Bass.

O'Keefe, P. A., \& Garcia, L. L. (2014). The role of interest in optimizing performance and selfregulation.Journal of Experimental Social Psychology, 53, 70-78.

Osborne, J. (2007). Science education for the twenty first century. Eurasia Journal of Mathematics, Science \& Technology Education, 3(3), 173-184.

Pallant, J. (2007). SPSS survival manual: A step by step guide to data analysis using SPSS for windows. Maidenhead: Open University Press.

Pintrich, P. R. (1988). A process-oriented view of student motivation and cognition.In J. S. Stark \& L. Mets (Eds.), Improving teaching and learning through research.New directions for institutional research, 57 (pp. 55-70). San Francisco: Jossey-Bass.

Pintrich, P. R. (2000). Multiple goals, multiple pathways: The role of goal orientation in learning and achievement. Journal ofEducational Psychology, 92, 544-555.

Pintrich, P. R. (2000). The role of goal orientation in self-regulated learning. In M.Boekaerts, P. R. Pintrich \& M. Zeidner (Eds), Handbook of Self-Regulation (pp. 452-502). San Diego, CA: Academic Press.

Pintrich, P. R., \& De Groot, E.V. (1990).Motivational and self-regulated learning components of classroom academic performance.Journal of Educational Psychology, 82, 33-40.

Pintrich, P. R., \& Garcia.T. (1991).Student goal orientation and self-regulation in the college classroom. In M. L. Maehr \& P. R. Pintrich (Eds.), Advances in motivation and achievement: Goals and selfregulatorvprocesses (Vol.7, pp. 371-402), Greenwich, CT: JAI Press.

Pintrich, P. R., Roeser, R. W., \& De Groot, E. A. M. (1993). Classroom and individual differences in early adolescents' motivation and self-regulated learning.Journal of Early Adolescence, 14, 139-161.

Pintrich, P. R., Smith, D. A. F., Garcia, T., \& McKeachie, W. J. (1991).A manual for the use of the Motivated Strategies for Learning Questionnaire (MSLQ). Ann Arbor, MI: National Centre for Research to Improve Postsecondary Teaching and Learning, The University of Michigan.

Pintrich, P. R., \& Schunk, D. H. (2002).Motivation in education: Theory, research, and applications. Columbus, $\mathrm{OH}:$ Merrill.

Poondej, C., Koul, R., \& Sujivorakul, C. (2013).Achievement goal orientation and the critical thinking disposition of college students across academic programmes.Journal of Further and Higher Education, 37(4), 504-518.

Renninger, K. A., \& Hidi, S. (2002). Student interest and achievement: Developmental issues raised by a case study. In A. Wigfield \& J. S. Eccles (Eds.), Development of achievement motivation (pp. 173-195). New York, NY: Academic.

Sansone, C., \& Thoman, D. B. (2005).Interest as the missing motivator in self-regulation.European Psychologist, 10, 175-186.

Senler, B., \& Sungur, S. (2007, November). Hedef yönelimi anketinin Türkçe’ye çevrilmesi ve adaptasyonu. A paper presented at 1. Ulusal İlköğretim Kongresi, Ankara, Turkey.

Senler, B., \& Sungur S. (2009). Parental influences on students' self-concept, task value beliefs, and achievement in science. The Spanish Journal of Psychology 12(1), 106-117.

Schraw, G., \& Moshman, D. (1995).Metacognitive theories.Educational Psychology Review, 7(4), 351-371.

Schraw, G., Crippen, K. J., \& Hartley, K. (2006).Promoting self-regulation in science education: Metacognition as part of a broader perspective on learning.Reseacrh in Science Education, 36, 114-139.

Schiefele, U. (1991). Interest, learning and motivation.Educational Psychologist, 26, 299-323.

Schiefele, U., Krapp, A., \& Winteler, A. (1992). Interest as a predictor of academic achievemnt: A metaanalysis of research. In K. A. Renninger, S. Hidi, \& A. Krapp (Eds.), The role of interest in learning and development (pp.183-212). Hillsdale, NJ: Erlbaum.

Singh, K., Granville, M., \& Dika, S. (2002). Mathematics and science achievement: Effects of motivation, interest, and academic engagement. Journal of Educational Research, 95, 323-332. 
Somuncuoğlu, Y. \& Yıldırım, A. (1999).Relationships between achievement goal orientations and use of learning strategies.Journal of Educational Research, 92(5), 267-278.

Sungur, S. (2004).The implementation of problem-based learning in secondary school biology courses.Unpublished dissertation, Middle East Technical University, Ankara, Turkey.

Sungur.S. (2007).Modeling the relationships among students' motivational beliefs, metacognitive strategy use, and effort regulation. Scandinavian Journal of Educational Research, 51(3), 315-326.

Sungur, S., \& Senler, B. (2009).An analysis of Turkish high school students' metacognition and motivation.Educational Research and Evaluation, 15(1), 45-62.

Sungur, S., \& Senler, B. (2010).Students' achievement goals in relation to academic motivation, competence expectancy, and classroom environment perceptions.Educational Research and Evaluation, 16(4), 303324.

Sungur, S., \& Tekkaya, C. (2006).Effects of problem-based learning and traditional instruction on self-regulated learning.Journal of Educational Research, 99(5), 307-317.

Tai, R. T., Liu, C. Q., Maltese, A. V., \& Fan, X. T. (2006).Planning early for careers in science.Science, 312 , 1143-1144.

Taylor, N., \& Corrigan, G. (2005). Empowerment and confidence: Pre-service teachers learning to teach science through a program of self-regulated learning, Canadian Journal of Science, Mathematics and Technology Education, 5(1), 41-60.

Tung-hsien, H. (2004). The relations among trichotomous achievement goals, self-efficacy, and self-regulation in EFL sixth-grade classes in Taiwan.Journal of National Taipei Teachers College, 17, 11-134.

Valle, A., Cabanach, R. G., Nunez, J. C., Gonzalez-Pienda, J., Rodriguez, S., \& Pieniro, I. (2003).Cognitive, motivational, and volitional dimension of learning.Research in Higher Education, 44, 557-580.

Wigfield, A., \& Eccles, J. S. (2000).Expectancy-value theory of achievement motivation.Contemporary Educational Psychology, 25, 68-81.

Wolters, C., Yu, S. \& Pintrich, P. (1996). The relation between goal orientation and students' motivational beliefs and self-regulated learning.Learning and Individual Differences, 8, 211-238.

$\mathrm{Xu}$, J. (2008). Models of secondary students' interest in homework: A multilevel analysis. American Educational Research Journal, 45, 1180-1205. 